\title{
HIV/AIDS in South Africa: an overview
}

\author{
HIV/AIDS na África do Sul: um panorama
}

Leah Gilbert 1

Liz Walker 2

\footnotetext{
1 Department of Sociology, University of the Witwatersrand, Johannesburg. Private Bag 3, WITS, 2050, South Africa. 029leah@muse.wits.ac.za 2 Wits Institute for Social and Economic Research, University of the Witwatersrand, Johannersburg. Private Bag 3, WITS, 2050, South Africa. walker@wiser.wits.ac.za
}

\begin{abstract}
This paper presents an overview of the development of HIV/AIDS in South Africa, taking into consi deration the social context and analyzing the factors most likely to have influenced its spread as well as the societal response to it. The authors argue that macro factors such as social and political structures, in addition to behavioral ones, have combined to shape the course of the epidemic. Since various factors linked to social inequalities have combined to shape the pattern and growth of the HIV/AIDS epidemic in South Africa, it is inappropriate to focus on onIy one dimension in an attempt to combat the epidemic. Following the psycho-socio- environmental model, all potential contributing elements need to be addressed simultaneously. This calls for a true interdisciplinary and multi-sectorial approach. It al so requires great commitment as well as strong political will.
\end{abstract}

Key words HIV; Acqui red Immunodeficiency Syndrome; Disease Outbreak; Socioeconomic Factors; Epidemiology

Resumo O artigo apresenta um panorama da epi demia de HIVIAIDS na África do Sul, levando em conta o contexto social e anal isando os principais fatores que influenciaram sua disseminação, assim como, a resposta pela soci edade sul-africana. As autoras argumentam que fatores macro, tais como estruturas sociai s e políticas, além de fatores comportamentais, agiram em conjunto para configurar o curso da epidemia. Uma vez que vários fatores, associados a desi gualdades sociais, influenciaram o padrão e o cresci mento da epi demia do HIV/AIDS na África do Sul, éinapropriado focalizar apenas uma dimensão da epi demia na tentativa de combatê-la. Todos os el ementos que possam influenciar o curso da epidemia devem ser abordados simultaneamente, de acordo com o modelo psico-sóci o-ambi ental. Tal abordagem deve ser verdadeiramente interdisciplinar e multi-setorial, o que também requer grande compromisso e vontade política.

Palavras-chave HIV; Síndrome de Imunodeficiência Adquirida; Surto de Doenças; Fatores Sócio-Econômicos; Epidemiologia 


\section{Introduction}

"South Africa has the fastest growing [HIV/AIDS] epidemic of any country in the world. Within five years, one South African will die of an AIDS-related illness every minute unless action is taken now" (Lowell, 2000:1). This is but one of many recent statements in the South African media which captures the gravity of the epidemic, its potential impact on society, and the urgent need for effective interventions. Highprofile media coverage is a relatively new phenomenon in South Africa: one of the epidemic's main features since the beginning has been silence. Although HIV/AIDS features prominently in the media and is fiercely debated in governmental and nongovernmental circles, the epidemic continues to grow rapidly, and efforts to combat it have not yiel ded the expected results.

HIV/AIDS is not merely a medical problem, but primarily a social one, as demonstrated by its spread as well as by the inability and inadequacy of the medical establishment to control and curtail its expansion. This understanding is in line with the psycho-socio-environmental (PSE) model of health and disease, in sharp contrast to the bio-medical model, which views health and disease "through the microscope" and offers technical solutions to what are largely social problems. Rather than keeping health and disease in a biological context, the PSE model analyzes them in a social context which takes a macroscopic view and offers a broader perspective. The model focuses on the promotion and maintenance of health through socioenvironmental and behavioral change (Gilbert et al., 1996). This paper presents an overview of the HIV/AIDS epidemic in South Africa, taking the social context into consideration and analyzing the factors most likely to have influenced both the epidemic's spread and the societal response to it. It is argued that macro factors such as social and political structures as well as behavioral ones have combined to shape the course of the epidemic and its outcome.

\section{Methodological concerns}

One of the main problems in South Africa is the inadequate quality of statistical information. All data must thus be interpreted carefully, recognizing potential inaccuracies, mainly in population estimates and registration of information. The general data presented in this paper are derived from five different sources: Health Systems Trust, Department of Health, Statistics
South Africa, UNISA's Market Research Bureau, and Community Agency for Social Inquiry (CASE).

\section{Socioeconomic and demographic characteristics of South African society}

South African society is marked by gross social inequalities, manifesting themselves mainly along racial, class, and gender lines. It is arguable that racial inequities (in the form of apartheid) have most significantly shaped the social profile and consequently health and health care of South Africa. Under the Population Registration Act of 1950, all South Africans were classified into a "population group" at birth and assigned a racial category, namely White, Indian, Coloured, and African. Although this act was repealed in 1991, its social and economic effects will remain present for a long time to come. Therefore statistics in this paper will be presented according to "population groups" or race where appropriate.

In 1999, $10.5 \%$ of the South African population were White, $2.5 \%$ Indian, $8.8 \%$ Coloured, and $77.2 \%$ African. The national average annual growth rate for 1991-1996 was 2.0\% and varied from $0.5 \%$ for Whites to $2.4 \%$ for Africans. The African population is young and expanding, with over $25 \%$ of the population below the age of 15 years. In contrast, the White population is aging and shrinking, with as much as $9.4 \%$ of the population aged 65 years or older. The percentage of the population in the economically active age brackets is smaller for the African and Coloured than for the White and Indian groups. The infant mortality rate is highest for the African population (48 per thousand) and lowest for Whites ( 7 per thousand). Mean national life expectancy at birth is 62 years for men and 68 for women. However, life expectancy ranges from 59 for Coloured males to 76 for White females (HST, 2000:405).

South Africa is classified as a middle-income country by the World Bank, but the economy declined severely in the 1990s, with negative growth rates in 1991 and 1992. The economic growth rate in 1994 increased to $2.5 \%$, still far from the 3.5\% estimated by the International Monetary Fund as necessary to reduce unemployment. In 2000 the economy was expected to grow by $3.5 \%$, but such forecasts have not materialized (Whiteside \& Sunter, 2000). Although all population groups experienced a moderate increase in real income over the past fifty years, the gap between rich and poor is great compared to many other developing 
countries of similar status. In 1991, White per capita incomes were more than 12 times those of Africans. However, income inequality within population groups has grown even faster and is greatest among Africans, where the poorest $40 \%$ earned only $6.4 \%$ of the income and the richest $10 \%$ earned $46.6 \%$ in 1991 . During that same year it was estimated that 17.3 million people and about half of all households lived below the minimum subsistence level. Twothirds of African households were estimated to live in poverty, compared to $6.7 \%$ of White households. These figures remained largely unchanged in 2001.

Although this paper does not explore the complexities of class and its relationship to race, for purposes of analytical clarity income is used as an indicator for class (Gilbert \&Walker, 2000).

Figure 1 is a clear demonstration of the relationship between class and race in the South African context.

Employment in the formal sector is an important guarantee of income, adequate food, and access to other necessary services. Unemployment in the formal sector now stands at about $40 \%$ of the work force. Apartheid policies, together with agricultural policies favoring large-scale agriculture, pushed millions of Africans off their land into impoverished reserves, homelands, and townships. At present the White agricultural sector owns $88 \%$ of arable land in South Africa. Historically, the South African economy was structured around a system of migrant labor which spanned the Southern African region, leading young men and women to leave the rural areas to find work in the mines and cities. Rapid and uncontrolled urbanization in the African population resulted in family breakdown, high levels of urban and rural poverty, and the rampant spread of diseases associated with impoverishment and population mobility (Marks \& Trapido, 1987).

Since education is recognized worldwide as a prerequisite for sustainable development and health, it also plays an important role in society's response to the HIV/AIDS epidemic. In South Africa, racial imbalances exist in education on every level, with African people most severely affected. The latest National Household Survey of Health Inequalities in South Africa (CASE, 1995) reported that $92 \%$ of persons responsible for household health care were women. Among Africans, 57\% had attained standard five education or less, compared with 50\% among Coloureds, 22\% among Indians, and $1 \%$ among Whites. Urbanization has been an important factor in determining both the population's health and its disease

\section{Figure 1}

Socioeconomic status by race. South Africa.

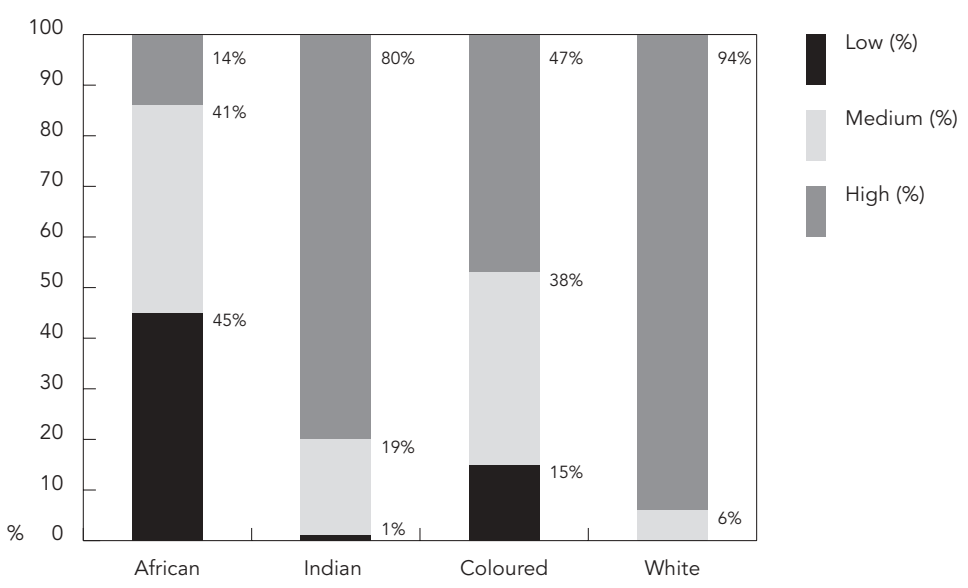

Source: Health Systems Trust, The Equity Gauge, 2000.

patterns. By 1985 , about $57 \%$ of the South African population was urbanized and located mainly in the major metropolitan areas. The country's urban population is predicted to double by the year 2010, creating an enormous challenge for planners of health, housing, and other social services. According to the 1991 census, $9 \%$ of the population lived in urban shantytowns, with inadequate provision of basic facilities such as safe water, sanitation, electricity, and health services.

The inequalities identified in South African society are reflected in the health sector. Nearly three-fifths (58\%) of the total health budget was spent on private health services which serve approximately $20 \%$ of the population, mostly White and those from the higher income groups. The result is fewer health care resources for poorer people. Coupled with the poor living conditions described earlier, this also means less available heal th care for people with higher infant mortality rates and general morbidity levels.

The National Household Survey of Health Inequalities in South Africa (CASE, 1995) revealed a range of inequalities along racial lines. Of particular relevance to this paper is the differential access to health care by race, whereby a larger proportion of Africans (37\%) and Coloureds (30\%) had not received health care in the previous year as compared to Whites (17\%) and Indians (18\%). These findings also support the notion that those most in need of 
health care do not necessarily have access to it. Data from this survey also indicate that, in general, poverty, overcrowding, and unemployment are associated with lack of health care, particularly among Africans and Coloureds.

Although class/racial inequalities overshadow other types of inequalities, of specific relevance to this paper are gender inequalities prevalent in South Africa. It is argued that gender relations in general, and in South Africa in particular, operate mainly to privilege men and to subordinate women. Gender differences and inequalities in South Africa can be demonstrated at various levels, some of which are employment, control over reproduction, the law, education, and sexuality (Gilbert \& Walker, 2000). Unemployment rates are higher for women than men in all racial categories. In 1995, 47\% of economically active African women and $29 \%$ of African men were unemployed, compared to only $4 \%$ of White men and $8 \%$ of White women. On average, women earn between 72 and $85 \%$ of what men with similar education earn and continue to predominate in low-skilled and low-paid occupations. African women are the poorest, most economically marginalized, and least educated sector of the South African population, thus placing them at the bottom of the health pile in this country (Gilbert $\&$ Walker, 2000; Gilgen et al, 2000; Susser \& Stein, 2000).

This brief overview of the South African social context has served to provide insight into the historical progression as well as the current state of HIV/AIDS in South Africa.

\section{History of the HIV/AIDS epidemic}

The first AIDS cases reported in South Africa occurred among homosexual men in 1982. Prior to the development of HIV antibody tests, about 100 blood transfusion-related infections are known to have occurred between 1982 and 1985. HIV testing of stored sera from a community survey in rural KwaZulu-Natal and blood donor data demonstrated a very low prevalence of HIV in the general population in 1985 (Abdool-Karim, 2000).

Figure 2 depicts the number of AIDS cases in South Africa by year of diagnosis and exposure category. These data are derived from information released by the then Department of National Health and Population Development based on anonymous data supplied by the South African Institute of Medical Research (SAIMR), as well as Epidemiological Comments. This figure represents the AIDS epidemic between 1982-1992 according to mode of transmission.

This paints a clear picture with regard to the early pattern of the epidemic. Like the dominant patterns in Western countries in the early to mid-1980s, the epidemic was confined mainly to homosexual males and as of 1988

Figure 2

AIDS cases by pattern of transmission per year. South Africa, 1986-1992.

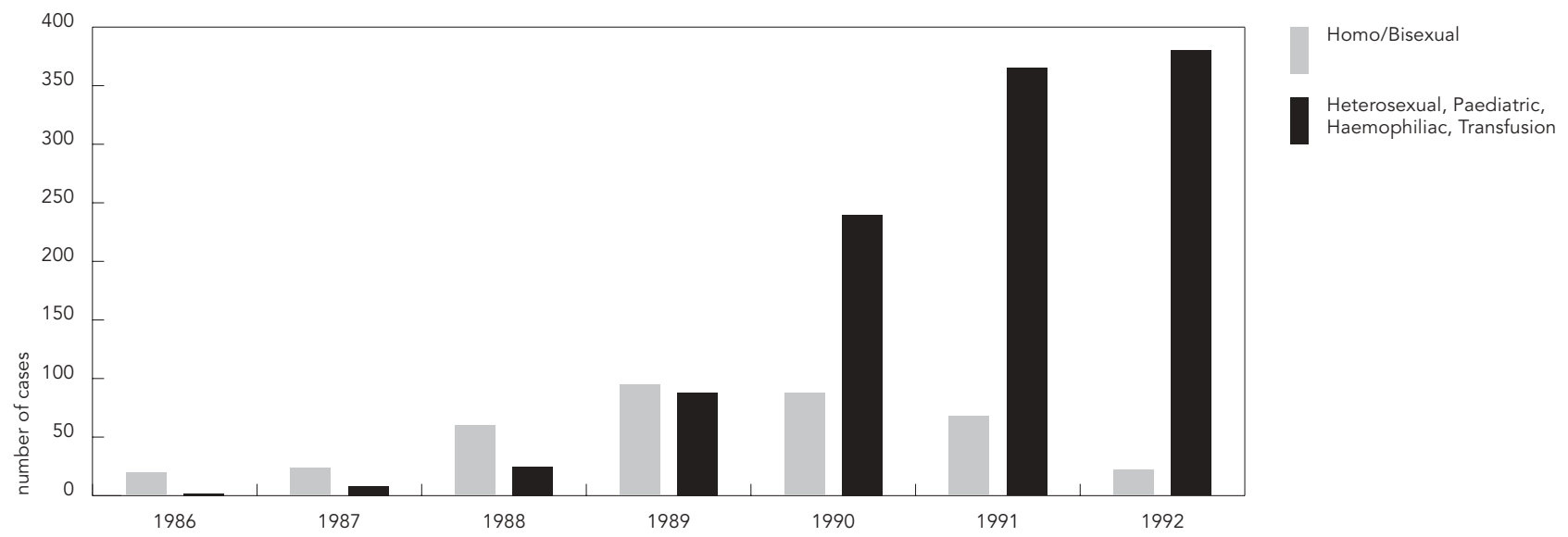

Source: Information released by the Department of National Health and Population Development, based on anonymous data supplied by the South African Institute of Medical Research. 
(within this exposure category) seemed to be under check (Ijsselmuiden et al., 1988).

Based on Figure 2 it can be argued that this early pattern was soon to change, as indicated both by the data as well as through an understanding of the unique South African social conditions and context discussed above. By the late 1980s it was already quite obvious that the future growth of the epidemic would mainly affect the heterosexual population and would be compounded by pediatric AIDS, as a consequence of the involvement of women of child-bearing age.

However, unlike the pattern in Western countries, although recreational drug use is extensive, injecting drug use has been limited, and needle sharing does not appear to be a very important mode of HIV transmission in South Africa, with sexual intercourse remaining as the main mode (Abdool-Karim, 2000).

HIV- 1 is the dominant strain in South Africa, with HIV-2 remaining rare. HIV-1 molecular epidemiology has demonstrated that the clade $B$ virus predominates among gay men, and that clade $\mathrm{C}$ is associated with heterosexual transmission. According to Abdool-Karim (2000:11), these findings "suggest two independent HIV epidemics unfolding in South Africa; the first and earlier epidemic started in the early 1980s in which HIV has spread mainly through same sex contact and contaminated factor VIII, while the second and most recent epi demic started in about 1987 among heterosexuals, with a con- comitant epidemic among children infected through perinatal transmission".

In 1990 the Department of Health began testing pregnant women attending public health sector prenatal clinics; thus the HIV/ AIDS data from 1991 onwards have been obtained from the national annual survey. These data are not faultless, but are the only statistical material available on a national level. There are arguments to suggest both an under- and over-estimation of the true size of the epidemic from these data. Among sexually active adults, the prenatal survey prevalence figures do not reflect the lower overall risk of men, people who are less sexually active, and communities using the private sector. On the other hand, recent studies indicate that fertility among HIV-positive women is substantially lower than among uninfected women, suggesting that prenatal data may in fact underestimate HIV prevalence in reproductive-age women in many communities. On balance, however, it is felt that these prenatal data are sufficient for purposes of estimating current infection rates in the general population and projections of these rates into the future (ABT Associates Incorporation, 2000).

The data collected in these annual surveys are summarized in Figure 3, clearly showing the rapid growth of the epidemic in South Africa as a whole.

Due to the sociological significance of race in South Africa, it is important to examine the

Figure 3

HIV prevalence trends. South Africa, 1990-1999.

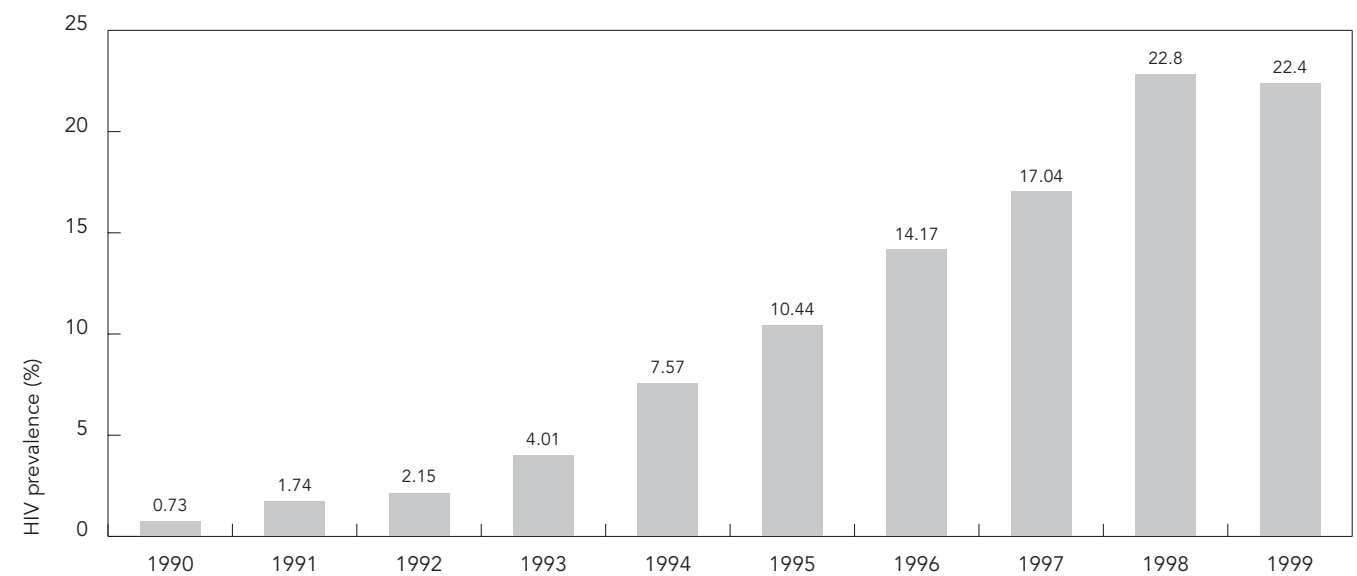

Source: Department of Health, 2000. 
available HIV/ AIDS figures according to these categories. Note should be taken that prior to 1994 all statistics in South Africa were collected and presented by "population group", as discussed earlier.

Figure 4 is an example of AIDS cases presented according to racial categories and clearly illustrates how with the shift of the epidemic from the mainly homosexual pattern to the heterosexual one, both the percentage and ratio of infected African people have increased as predicted. Since 1994 the category of "race" or "population group" has been excluded from the data collected. However, its social impact is evident, although camouflaged, in other categories such as geographic location (provinces) and/ or class (income groups).

\section{Current state of the epidemic}

Following the new political dispensation (1994), South Africa has been divided into nine provinces with the aim of redressing some of the past inequalities and facilitating smother administration and governance. However, the reality is that there are striking inequalities between the provinces on various levels.

Examining the latest HIV prevalence data by provinces, Figure 5 reveals a differential distribution of the burden of HIV/AIDS between the provinces, with KwaZulu Natal having the highest rates (32.5\%) followed by Free State with $27.9 \%$. It can be argued that these differences are most likely influenced by the social factors which facilitate and expedite the spread of the disease.

Racial composition (population group) varies greatly between the provinces (Figure 6). This is of particular significance in the South African context due to the confluence of class and race, in part because of the legacy of apartheid. It acquires additional significance once examined in combination with socioeconomic status by race (Figure 1 ).

Socioeconomic status is a good indicator of burden of disease. The lower the socioeconomic status of a community the more likely it is to be unhealthy. Data in Figure 1 manifest the gross disparities between racial groups, whereby $94 \%$ of the White population, in contrast to only $14 \%$ of the African population, has a high socioeconomic status. The unemployment rate at the time of the 1996 population census was $34 \%$. An analysis of unemployment rates by provinces (Statistics South Africa, 2000) identifies four with higher unemployment rates than the country as a whole: Eastern Cape (49\%), Northern Province (46\%), KwaZulu-Natal (39\%), and North West (38\%). These are also the provinces with the lowest levels of disposable income per capita (UNISA, 2000). Although these data were derived from different sources, they clearly attest to the existence of inequalities between the provinces.

Figure 4

Transmission category by race and year of diagnosis. South Africa.

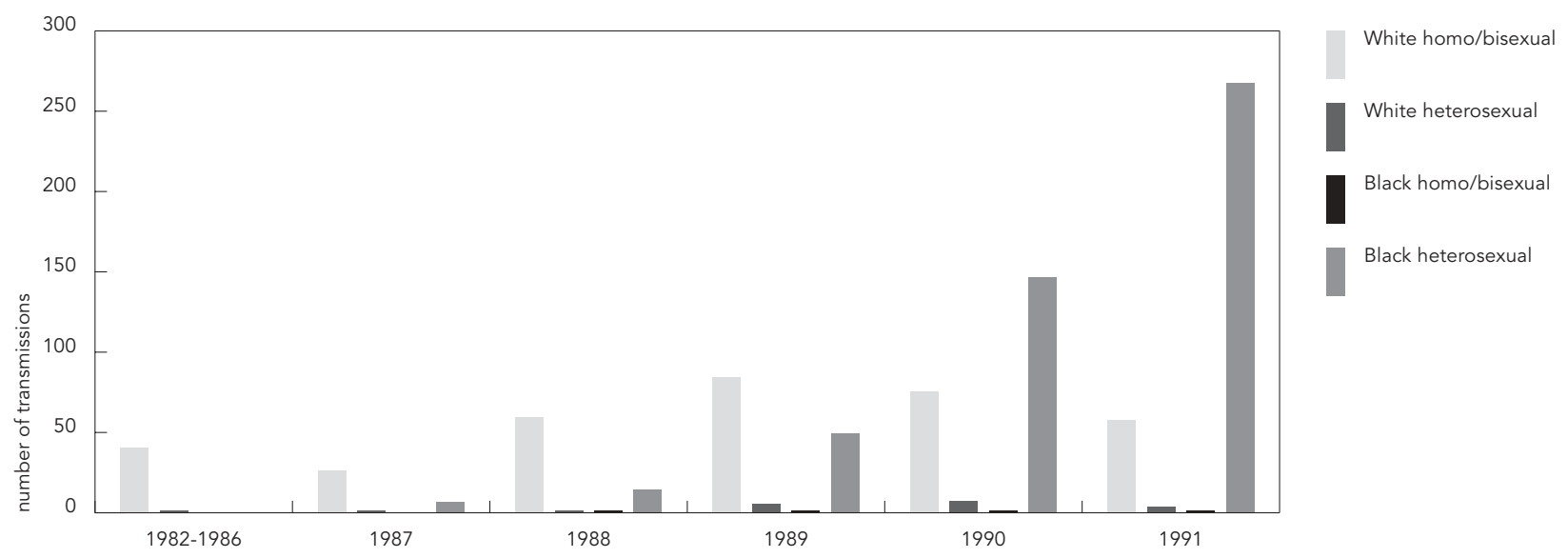

Source: Information released by the Department of National Health and Population Development, based on anonymous data supplied by the South African Institute of Medical Research. 
Figure 5

HIV prevalence by province. South Africa, 1999.

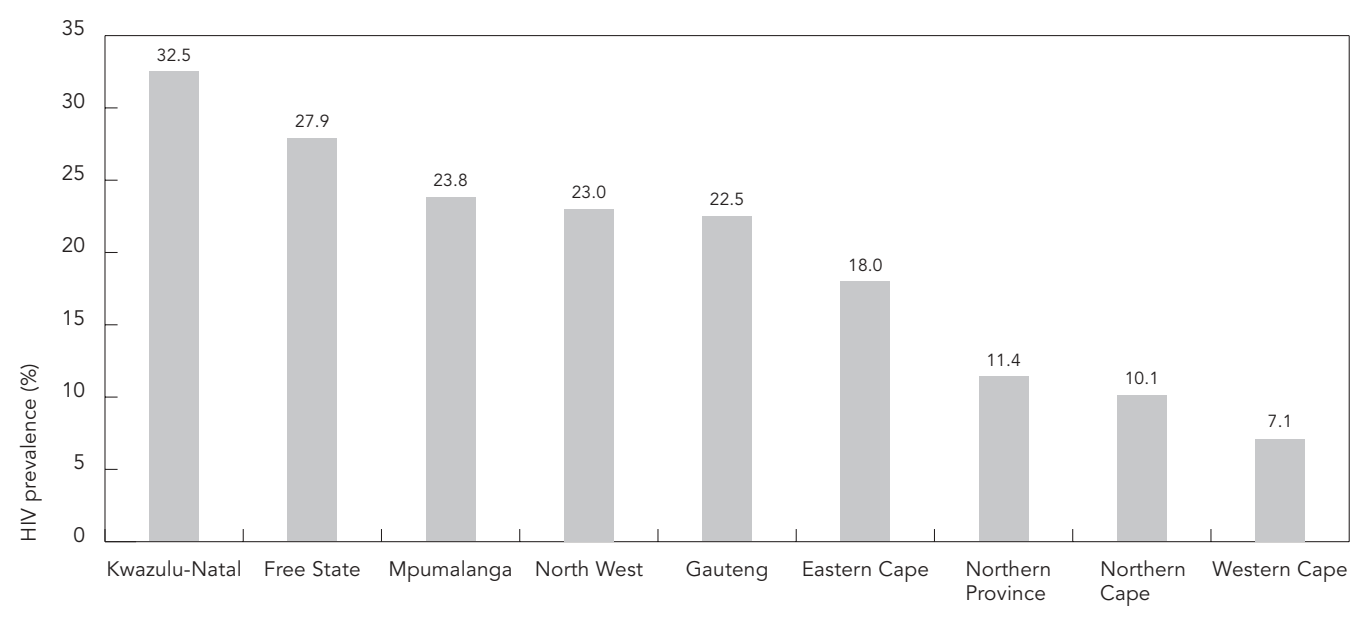

Source: Department of Health, 2000.

Figure 6

Population group by province. South Africa, 1996.

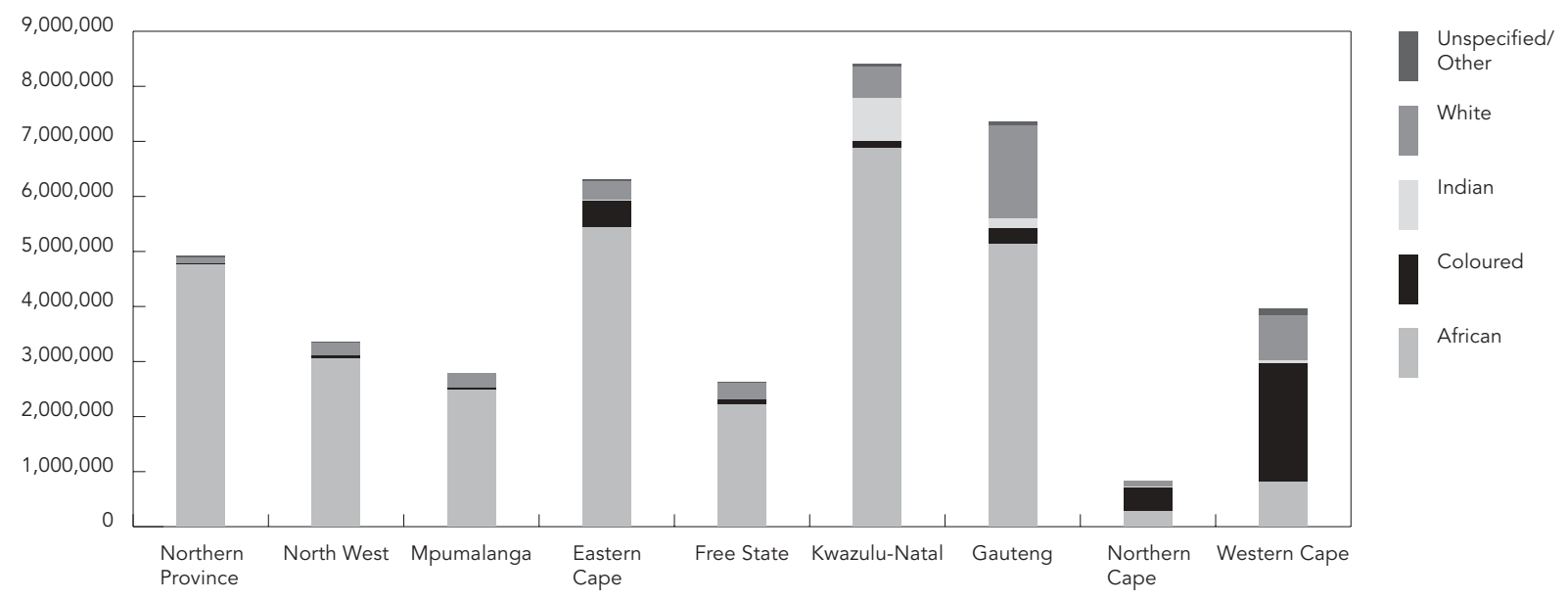

Source: Statistics South Africa, 2000. 
The latest report by the University of South Africa's Bureau of Market Research (UNISA, 2000) concludes that South African inequality remains amongst the highest in the world, giving the country the status of one of the world's most unequal societies (Katzenellenbogen, 2000). The report points to one of the most vivid indications of South African inequality: the sharply differing levels of the human development index for the various provinces. Gauteng (South Africa's economic hub) and the Western Cape have the same ranking in terms of the human development index, at 0.73 , similar to a middle-income country likeTurkey. By contrast, the Northern Province, the poorest in South Africa, has a human development index of 0.57 , close to that of Zimbabwe, which ranks 130th in the index. Overall, South Africa has a human development index of 0.67 , meaning that it is far short of the 0.8 that the UNDP considered necessary for a high level of human development (Katzenellenbogen, 2000).

Younger people are the most severely affected by HIV/AIDS. This is not surprising, since about $45 \%$ of the South African population (16 million) are under 20 years of age. It is estimated that over $60 \%$ of all new infections currently occur among individuals between 15 and 25 years of age, with women generally being infected earlier than men (Figure 7). The overall rate is also higher for women: $35 \%$ as opposed to $29 \%$ for men in the $15-30$ age group (ABT Associates Incorporation, 2000).
This pattern is similar to that of most SubSaharan countries (Ndiaye, 2000; Turshen, 1991; Whiteside \& Sunter, 2000). Data from a recent study in Carletonville (a mining town on the West Rand of Gauteng) support and augment this alarming scenario: an extraordinarily high rate of infection was found among adolescent girls, reaching nearly $60 \%$ at 25 years of age (Gilgen et al., 2000).

\section{Social and economic impact of the epidemic}

An epidemic of this magnitude in a population will inevitably have dire economic and social consequences. These will be manifested on the macro-societal and community levels and be experienced by families and individuals. Although the epidemic is projected to peek only around 2010 (Whiteside \& Sunter, 2000), its impact is already evident on various levels. Reports emanating from the commercial sector indicate high levels of absenteeism and illhealth in the workplace; the number of AIDS orphans is al ready placing a serious burden on welfare and health agencies; the local municipalities are predicting a lack of space and infrastructure to cope with the growing numbers of the dead; the existing health care facilities are struggling to cope with the treatment of AIDSrelated conditions; and the government is unwilling to provide effective treatment to all HIV-

Figure 7

Proportion of all new infections projected between 1995 and 2010 by gender and age categories.

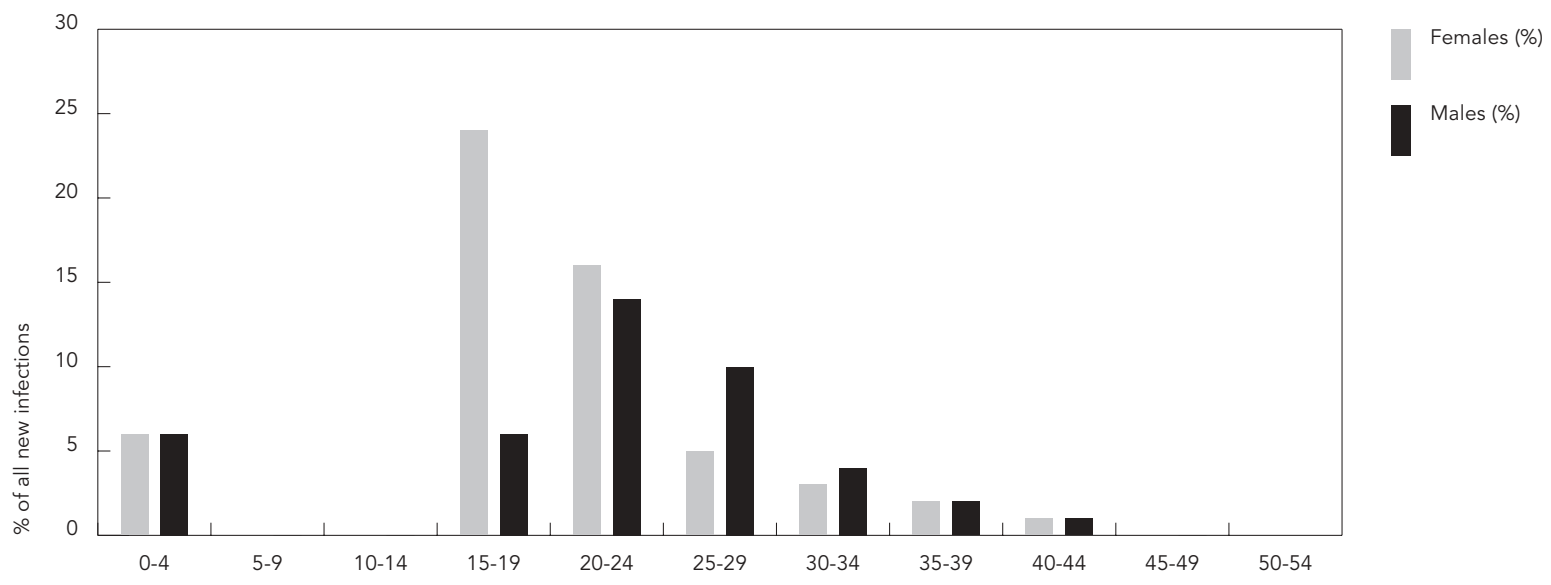

Source: ABT Associates Incorporation, 2000. 
infected people, including pregnant women. This unacceptable government policy has been a major source of debate in public health circles.

AIDS is projected to increase infant mortality two-fold and child mortality three-fold, erasing gains made over 50 years in child survival. By 2010 at least 4 million South Africans will have died of AIDS (IMPACT Project, 2000). Life expectancy will decrease from 63 in 1999 to 40 in 2010 (Bourne, 2000). This and the fact that most of the dead will be in their most economically productive years will have profound effects both on the population structure, the economy, and society as a whole.

\section{Societal response}

Government response before the 1994 election was inadequate and very slow. Although the state acknowledged that AIDS cases had been diagnosed since 1982, it did not launch any educational campaigns until several years later. Once launched, these campaigns were ill-conceived, racist, judgmental, and based on fear. The government did not allow any campaigning in schools or on public television or radio. Due to the administration's conservative nature there was an absolute reluctance to discuss sex in public fora. Although the government has changed, this reluctance persists, thus seriously hampering health promotion interventions.

Needless to say, this approach has been strongly criticized by concerned health professionals and various bodies with a more responsible vision (Crewe, 1997; Evian, 1993). However, protests fell on deaf ears and were not translated into effective intervention. Most of these bodies convened in 1992 to form NACOSA (National AIDS Committee of South Africa) which was mandated to develop a national AIDS strategy and implementation plans. By 1994, South Africa had a National AIDS Plan based on the understanding of the disease, its social determinants, and its potential impact on society as a whole. As asserted by Crewe (2000:27): “No one could claim that the country did not know what it was facing". The National Plan was accepted and endorsed by the Government and supported by a range of other relevant organizations. The crucial role of people living with HIV/AIDS was recognized, and they were to be involved in all stages of policy and program planning and implementation. Although it seemed at the time that all parties were fully committed, the plan did not come together, and "instead South Africa has been in many ways touched by the vengeance of AIDS" (Crewe, 2000:28). It is beyond the scope of this review to examine the reasons behind this situation, but serious lessons for future public health programs can be learned from it (Crewe, 2000; Marais, 2000; Schneider \& Stein, 2001).

Following the failure of the state to intervene effectively, society at large was mainly ignorant at the beginning and prejudiced throughout, maintaining the deafening silence and in combination with the social factors outlined earlier facilitating the epidemic's rapid growth.

\section{Discussion and conclusions}

There is no doubt that the HIV/AIDS epidemic in South Africa is at a critical phase. According to Crewe (2000:23), it has three main characteristics: "rapid and unchecked growth"; "a lack of any coherent policy documents on crucial issues"; and "failure of public prevention campaigns to havean impact".

The overview presented in this paper confirms this, but suggests a fourth feature, pertinent to the understanding of the epidemic in South Africa, namely, that most of the people affected by the epidemic are disadvantaged in terms of class, race, and gender, and are thus also more vulnerable (Gilbert \& Walker, 2000). It is evident that we must take both the social and biological dimensions of HIV/AIDS into account. However, the South African scenario supports the notion that the social dimension is far more pervasive and central than is usually believed, even by public health practitioners (Crewe, 1997).

There are a number of social factors which have influenced the pattern and severity of the HIV/ AIDS epidemic in South Africa. According to ABT Associates Incorporation (2000), these include: established epidemics of other sexually transmitted diseases; disrupted family and communal life, due in part to apartheid, migrant labor patterns, and high levels of poverty in the region; good transport infrastructure and high mobility, allowing for rapid movement of the virus into new communities; resistance to condom use, based on social and cultural norms; the low status of women in society and within relationships; social norms that accept or encourage large numbers of sexual partners, especially for men; and parallel norms that frown upon open discussion of sexual matters, including sex education for children and teenagers.

As a range of factors linked to social inequalities have combined to shape the pattern 
and growth of the HIV/ AIDS epidemic in South Africa, it is inappropriate to focus only on one dimension in an attempt to combat the epidemic. Following the psycho-socio-environmental model, all potential contributing elements need to be addressed simultaneously. This calls for a true interdisciplinary and multisectorial approach. It also requires great commitment as well as strong political will.

\section{References}

ABDOOL-KARIM, Q., 2000. Trends in HIV/ AIDS infection: Beyond current statistics. South African Journal of International Affairs, 7:1-21.

ABT ASSOCIATES INCORPORATION, 2000. The Impending Catastrophe: A Resource Book on the Emerging HIVIAIDS Epidemic in South Africa. Johannesburg: Love Life Programme.

BOURNE, D., 2000. Demographic implications for development in South Africa as a result of the AIDS epidemic - A graphic review. Urban Health and Development Bulletin, 3:8-12.

CASE (The Community Agency for Social Inquiry), 1995. The National Household Survey of Health Inequalities in South Africa. Durban: Henry J. Kaiser Family Foundation.

CREWE, M., 1997. How marginal is a marginalised group? Social Science and Medicine, 45:967-970.

CREWE, M., 2000. South Africa: Touched by the vengeance of AIDS - Responses to the South African epidemic. South African Journal of International Affairs, 7:23-37.

EVIAN, C., 1993. The socio-economic determinants of the AIDS epidemic in South Africa - A cycle of poverty. South African Medical Journal, 83:635636.

GILBERT, L.; SELIKOW, T. A. \& WALKER, L., 1966. Society, Health and Disease - An Introductory Reader for Health Professionals. Johannesburg: Ravan Press.

GILBERT, L. \& WALKER, L., 2000. Treading the Path of Least Resistance: HIV/AIDS and Social Inequalities: A South African Case Study. In: XVth International Conference on the Social Sciences and Medicine বhttp:// www.msoc-mrc.gla.ac.uk/ Social ScienceMedicine/ssm.html>.

GILGEN, D.; CAMPBELL, C.; WILLIAMS, B.; TALJAARD, D. \& MACPHAIL, C., 2000. The Natural History of HIV/AIDS in South Africa: A Biomedical and Social Survey in Carletonville. Johannesburg: Council for Scientific and Industrial Research.

IJSSELMIDEN, C. B.; STEINBERG, M. H.; PADAYACHEE, G. N.; SCHOUB, B. D.; STRAUSS, S. A.; BUCH, E.; DAVIES, J. C.; DE-BEER, C.; GEAR, J. S. \& HURWITZ, H. S., 1988. AIDS and South Africa: Towards a comprehensive strategy. Part III. The role of education. South African Medical Journal, 73:465-467.
IMPACT PROJECT (Implementing AIDS Prevention and Care Project), 2000. Corridors of Hope in Southern Africa. Virginia: Family Health International.

HST (Health Systems Trust), 1996. South African Health Review 1995. Durban: Health Systems Trust.

KATZENELLENBOGEN, J., 2000. Report confirms gulf between rich and poor. Business Day on the web, 25July «tttp:// www.bday.co.za/ bday/ index/ direct/ 0,3524,6078-0,00.html>

LOWELL, J., 2000. SA AIDS death rate heading for one a minute. Clinic, 22 November 2000 \&ttp:// www. iclinic.co.za/ nov00/ reuters/ aidsstats22.htm>.

MARAIS, H., 2000. To the Edge: AIDS Review 2000. Pretoria: University of Pretoria.

MARKS, S. \& TRAPIDO, S., 1987. The Politics of Race, Class \& Nationalism in Twentieth Century South Africa. London: Longman.

NDIAYE, C. F., 2000. Women and AIDS in Africa: The experience of the society for women and AIDS in Africa. South African Journal of International Affairs, 7:59-66.

SCHNEIDER, H. \& STEIN, J., 2001. Implementing AIDS policy in post-apartheid South Africa. Social Science and Medicine, 52:723-731.

STATISTICSSOUTH AFRICA, 2000. Stats in Bri ef 2000. Pretoria: Government.

SUSSER, I. \& STEIN , Z., 2000. Culture, Sexuality, and Women's Agency in the Prevention of HIV/AIDS in Southern Africa. American Journal of Public Health, 90:1042-1048.

TURSHEN, M. (ed.), 1991. Women and Health in Africa. New Jersey: Africa World Press.

UNISA (University of South Africa), 2000. Report of the Bureau of Market Research, July 2000. Pretoria: University of South Africa Press.

WHITESIDE, A. \& SUNTER, C., 2000. AIDS: The Challenge for South Africa. Cape Town: Human \& Rousseau, Tafelberg.

Submitted on 1 March 2001

Final version resubmitted on 8 August 2001

Approved on 7 November 2001 